\title{
Black Students' Support for the System
}

\section{Donald E. Whistler \\ University of Central Arkansas}

Abstract: Employing a volunteer sample of 123 black students, this research finds their political trust in the abstract level of the nation to be high but support for its political institutions, except the United States Supreme Court, to be low. While largely from lower socio-economic backgrounds, the sample is, however, sanguine regarding the effectiveness of the socioeconomic system to improve the racial climate and to produce their life-work desired. Support for within-the-system political activities is high and no support exists for racial separation. Relationships between socio-economic backgrounds, trust in the political system (legitimacy), and systemic effectiveness, on the one hand, and support for conventional/unconventional political activities, on the other, were very scattered and weak.

\section{Overview, Terms, and Measurement}

The importance of the stability of a political system has long been a theoretical and practical concern of students and practitioners of politics. ${ }^{1}$ Recently, researchers have begun to wrestle empirically with the concept of the stability of a political system, and the effects of variables such as socio-economic background, political legitimacy, and systemic effectiveness upon a system's stability. The focus of this study is upon these matters with a sample of black Americans.

Systemic stability refers to the endurance capacity of a set of political institutions over time. It is the "dependent" variable in this study, i.e., what the study seeks to "explain". Conceptualizing behaviors that may be considered supportive of an ongoing set of political structures is not a straightforward process. It is reasonable, however, to assume that behaviors which do not challenge or seek to change the on-going system are supportive, e.g., conventional political participation within the given system. On the other hand, violent actions, or ideologically hostile postures may be considered non-supportive. ${ }^{2}$ In this study three measures of systemic stability are used: (1) tactics considered appropriate to meet blacks' political 
needs, (2) perceptions of the meaning of "black power", (3) support for black racial separation. The questions used to measure these are contained in Tables 1, 2, and 3 respectively, along with the distributions of responses.

In this work the variables that are observed for their possible association with the preceding conception of systemic stability are: socio-economic background, legitimacy, and systemic effectiveness. These are the "independent" variables.

The suggestion that lower class background affects attitudes toward support for the on-going system has been widely voiced. Albeit, various researchers using different conceptualizations and measurement devices have investigated with mixed results. ${ }^{3}$ The relationship - or lack of it - is currently subject to intense controversy, particularly as it may apply to black Americans. ${ }^{4}$

Table 4 contains the questions employed in this study to suggest socio-economic background. Their distributions are in Table 4 also.

The notion that to survive a regime requires a certain amount of feeling among its citizenry that the regime is "right" and "proper" (i.e., that it is legitimate) has been one of political science's most treasured axioms. To conceptualize political legitimacy Easton employs trust in the abstract nation, its institutions, and the authorities who occupy the institutions. ${ }^{5}$ Although this understanding of political legitimacy is widely utilized, ${ }^{6}$ it suffers from the difficulty that feelings toward current incumbents may affect attitudes toward the institution, e.g., feelings toward Jimmy Carter may affect attitudes toward the presidency. Nevertheless, this problem does not present the difficulties that utilization of "alienation" as a measure of political legitimacy does. Alienation has a vast range of possible conceptualizations and operationalizations ranging from Marx to present social scientists.

In this project the levels ("objects" as Easton names them) of the abstract nation and its institutions are used, omitting the lowest authorities level. Tables 5 and 6 display the questions employed and the distributions.

Although legitimacy is commonly perceived as a necessary condition for the stability of a political system, it is not viewed as sufficient by scholars such as Seymour Martin Lipset. He views a system's capacity to deliver goods and statuses - systemic effec- 
tiveness - as also vital. ${ }^{7}$ Systemic effectiveness ${ }^{8}$ is measured in this research by the perception of whether the USA is seen as producing a more favorable racial climate, and whether it is viewed as delivering opportunity for the life's work desired by the black respondents. These are found in Table 7.

The data were obtained from 123 volunteer black students at the University of Central Arkansas in January, 1977. There were 465 black students at the University then. The questionnaire was prepared by the author and administered by black student officers of the Society For The Propagation of Black Culture on the campus. Although non-random, a sample of one-fourth the total number is substantial; and in this instance the representativeness of the sample is strongly suggested by the congruence of responses between this sample and national samples of black respondents reported in other research discussed below.

\section{Review of Literature and Descriptive Findings}

Research conducted in the 1950's and early 1960's reported less conventional political participation among blacks as compared to whites $^{9}$ except for non-visible political activities in the south. ${ }^{10}$ However, by the late 1960's blacks were participating in some aspects of conventional politics at rates higher than would be expected given other characteristics. ${ }^{11}$

With respect to unconventional political activities, the 1960 's witnessed major violence among blacks. In 1964-68 there were more than 320 major racial incidents in some 250 American cities, resulting in 50,000 arrests and 220 deaths. ${ }^{12}$ These nonsupportive riot activities, while widespread and spectacular, were highly disapproved as a personal action by a national sample of blacks with less than ten percent saying they would "be ready to use violence". while some 97 percent claimed they had not participated in any riot activity. ${ }^{13}$ The same researchers reported that somewhat more than half the blacks interviewed perceived the riots as "mainly a protest against unfair conditions." 14 They found that the strongest support for violent actions came from younger black males regardless of their educational level. ${ }^{15}$

The expression "black power" was perceived by slightly more 
than one-half ( 53 percent) of a 1971 sample of black Americans in systemically positive terms (fair share for blacks $=31$ percent, black racial unity $=22$ percent), although some 42 percent understood the term to convey feelings that could be interpreted negatively regarding the on-going system, e.g., "black rule over white" $=7$ percent, ridicule or obscenities $=4$ percent. ${ }^{16}$

Finally, black non-support for the on-going system could be expressed by a desire to separate from it. Traditionally black support for racial integration has been overwhelming. In 1967 nearly 90 percent of black Detriot interviewees favored integration. ${ }^{17}$ However, in what one hopes is an anomaly, support for integration was highest among college-educated in 1967 (93 percent), but by 1971 only 53 percent of college-educated blacks surveyed in Detriot supported racial integration. ${ }^{18}$ (The researchers suggested that this was a temporary strategy intended to render long-term racial integration more meaningful.)

This sample of black Arkansas college students displays a pronounced tendency toward non-violent, within-the-system activities as appropriate political actions with which blacks should achieve their political needs. (Table 1 contains this first measure of support/non-support.) The sample strongly interprets "black power" (the second measure of support/non-support found in Table 2) in systemic supportive terms, e.g., as meaning racial unity, and a fair share for blacks. And, on the third indicator of support/ non-support - racial separation attitudes displayed in Table 3 the sample extended no support for racial separation. Instead, they viewed group voting and an individualistic-orientation as the most appropriate tactics to achieve black's goals, the latter tactic was especially prominent among females.

More specifically, (Table 1) when asked what methods they thought were most appropriate to achieve black's needs, nonviolent with-in-the-system activities are ranked highest, withinthe-system protest actions in-between, and non-supportive activities ranked lowest. The rankings are in the same order for males and females whether the mean or median is used as the measure of central tendency. And, while females are slightly more inclined to rate non-violent actions higher, the differences are extremely small and statistically insignificant. To wit, "campaigning for black can- 
didates for office" ranked first, while "contacting public of ficials by letters or meetings" was second. These surely may be claimed as systemic supportive actions. Moreover, "campaigning against certain officials" is ranked third, and while negative it is less negative than the fourth ranked "taking part in protest meetings or

\section{Table 1}

\section{Ranking of Methods To Be Used To Achieve Blacks' Needs}

For the purpose of black Americans getting what they feel they need, which of the following do you think is the best way, second best, third best, and so forth? (Please put a "l" before the item you think is best, a " 2 " in front of the item you think is second best, and so forth until you have ranked them all.)

Rankings

1. Campaigning for black candidates for office.

2. Contacting public officials by letters or meetings.

3. Campaigning against certain public officials

4. Taking part in protest meetings or marches.

5. Taking part in sit-ins at government offices.

6. Refusing to obey an unjust law.

7. Taking part in a riot.
Black Males

Mean Median
Black Females

Mean Median

$\begin{array}{llll}2.09 * & 1.56 & 1.87 & 1.42\end{array}$

2.40

2.15

2.40

1.08

3.41

3.27

3.54

3.39

3.94

4.07

3.88

4.15

4.50

3.96

4.52

5.41

5.76

5.56

5.86

$\begin{array}{llll}6.47 & 6.84 & 6.62 & 6.88\end{array}$

* The values ranged from 1 to 7 with 1 highest and 7 lowest in rank. The items were in a scrambled arrangement on the questionnaire. 
marches." Finally, "taking part in sit-ins at government offices" is fifth in preferred actions, "refusing to obey a law that is unjust" is sixth, and "taking part in a riot" is last ranked.

The perception held of the meaning of "black power" (Table 2) is the second method of seeking to observe supportive/nonsupportive attitudes. Table 2 displays a clear ranking of systemic supporting views as high and non-supportive activities as low. Both black males and females ranked the possible meanings of "black power" in the same order with nearly the same intensity whether means or medians are used as the measure of central tendency. "Black racial unity" rated first. (However, black racial unity does not mean racial separation as the reader will see in the discussion of Table 3.) The item ranked second as the meaning of "black power" in Table 2 is "fair share for blacks," with "black rule over whites" ranked a distant third. "Ridicule of whites" was the next to last rated meaning of black power, and "violence" is placed in last position.

\section{Table 2}

\section{Rankings Given To The Different Meanings Of Term "Black Power"}

What does "Black Power" mean? (Please put a "1" before the item you think it most means, a "2" before the item you think it next most means and so forth until all are ranked).

Rankings

1. Black racial unity

2. Fair share for blacks

3 . Black rule over whites

4. Ridicule of whites

5. Violence
Black Males

Mean Median

1.49*

1.72

3.18

3.95

4.42
1.34

1.67

3.25

3.94

4.67
Black Females

Mean Median

$1.36 \quad 1.23$

$1.90 \quad 1.86$

$3.35 \quad 3.38$

$3.62 \quad 3.58$

$4.70 \quad 4.85$

${ }^{*}$ The values of each item ranged from 1 to 5 with 1 highest and 5 lowest in rank. The items were in a scrambled arrangement on 
the questionnaire. They were derived from Joel Aberbach and Jack Walker, Race and the City (Boston: Little, Brown, 1973), p. 109.

\section{Table 3}

\section{Attitude Toward Racial Separation}

Which of the following best describes your opinion?

\section{Blacks should separate}

Black Black Black

from whites and from

their own country.

2. Blacks should remain in

Males Females Total

America but should become

the most powerful group. $\quad 24 \%$ (12) $\quad 9 \%$ ( 6 ) $15 \%$ (18)

3. Blacks should remain in

America but should try to

gain equality by voting as

a group.

4. Blacks should remain in

$0 \%(0) \quad 0 \%(0) \quad 0 \%(0)$

America and each person should seek his or her

best life.

$50 \%(25) \quad 51 \%(36) \quad 51 \%(61)$

Attitude toward political racial separation (Table 3 ) is the third way that support or non-support for the on-going system is measured. There is no support among the black students surveyed for racial separation (Table 3 ), and only a small number support black hegemony with blacks remaining within the USA ( 15 percent). The majority ( 51 percent) advocate black group voting. This seems to be the meaning black students have in mind by "black racial unity" which was ranked the highest as the meaning of "black power" in the preceding discussions of Table 2. A large percentage (34 percent) are fundamentally individualistic, however, believing that blacks should remain in America but each person should seek his or her own best life. Black females are more inclined toward the individualistic position to an extent that is statistically significant 
(difference of means t-test probability $=0.018$ ). This was the only statistically significant difference between black males and females found throughout the study.

Looking now at the first of the "independent" variables, the sample contains the low levels of socio-economic family background anticipated from literature. ${ }^{19}$ Included in Table 4 is the evidence that while their fathers' occupations were of generally low status, their jobs were stable; and that a fifth of their mothers did not work.

\section{Table 4}

\section{Respondents' Family SES Background}

Status of

Fathers'

Occupation

High

Medium

Low
Black Black Status of

Males Females Mothers'

Occupation

$\begin{array}{rrl}7 \% & 3 \% & \text { High } \\ 40 \% & 35 \% & \text { Medium } \\ 53 \% & 62 \% & \text { Low } \\ & & \begin{array}{r}\text { Doesn't } \\ \text { Work }\end{array}\end{array}$

Black Black Males Females

How often is your father out of work?

Black

Males

Rarely

Occasionally

Often

Most of the Time
$76 \%$

$17 \%$

$2 \%$

$5 \%$
Black

Females

$80 \%$

$10 \%$

$2 \%$

$8 \%$

With respect to feelings of legitimacy in the American political system, Milton Morris has pointed out that blacks' long struggle for equal rights - from Frederick Douglass through the 1960's necessitated strong support for the basic political system of the United States, while criticizing the fact that this system was not extended to all citizens. ${ }^{20}$ Gary Marx's findings are in congruence with Morris' expectations. He has reported a national sample of 
black Americans who expressed strong trust in the abstract level of the "nation," with some 85 percent saying they considered America worth fighting for. ${ }^{21}$ Our sample of black students expressed a nearly identical overall response (Table 5) to Marx's national sample.

\section{Table 5}

\section{Support For Most General Level of "Nation"}

If the U.S. were to go to war today, do you think this country is worth fighting for?

$\begin{array}{llll} & \text { Black } & \text { Black } & \text { Black } \\ \text { Males } & \text { Females } & \text { Total } \\ \text { Yes } & 84 \%(41) & 87 \%(61) & 86 \%(102) \\ \text { No } & 16 \%(8) & 13 \%(9) & 14 \%(17)\end{array}$

This question came from Gary Marx, Protest and Prejudice (New York: Harper, 1969), p. 30.

Abramson's compilation of studies of different conceptualizations of political trust provides a composite picture of low black political trust. ${ }^{22}$ Regarding trust in the different levels of American government, Campbell and Schuman in their report prepared for the National Advisory Commission on Civil Disorders in 1968 found generally low perceptions of governmental efforts to solve problems at all levels of government with national and local levels receiving somewhat higher ratings than state government (national got 64 percent favorable, state 55 percent favorable, and local received 66 percent favorable). ${ }^{23}$ Aberbach and Walker report the low levels of trust in the levels of American government among blacks surveyed, but provide data only for the local level. ${ }^{24}$ Table 6 displays (questions 1-3) the anticipated low levels of trust found among our sample for all levels of U.S. government.

With respect to trust in the different branches of American government, researchers have previously noted high support among black Americans for the U.S. Supreme Court. ${ }^{25}$ Table 6 also 
displays this same attitude among our sample. The U.S. Supreme Court is the overwhelming choice as the branch that can be most trusted (70.5 percent). Moreover, this carries over to state and local institutions where courts are also more often chosen as most trustworthy, although local courts rate somewhat less trustworthy than the state Supreme Court. Our sample, then, yields the results we would have expected from the literature cited.

\section{Table 6}

\section{Trust In Political Institutions}

1. How much do you think you can trust the government in Washington to do what is right?*

$\begin{array}{ccc}\text { Black Males } & \text { Black Females } & \text { Total } \\ 2 \%(1)^{* *} & 1 \%(1) & 2 \%(2) \\ 2 \%(1) & 1 \%(1) & 2 \%(2) \\ 34 \%(18) & 26 \%(18) & 30 \%(36) \\ 54 \%(28) & 64 \%(45) & 59 \%(73) \\ 8 \%(4) & 7 \%(5) & 7 \%(9)\end{array}$

2. What about the state government in Little Rock, how much do you think it can be trusted to do what is right?

$\begin{array}{lrrr}\text { Always } & 2 \%(1) & 2 \%(1) & 2 \%(2) \\ \text { Just About Always } & 6 \%(3) & 3 \%(2) & 4 \%(5) \\ \text { Most of the Time } & 21 \%(11) & 32 \%(23) & 28 \%(34) \\ \text { Some of the Time } & 65 \%(34) & 56 \%(40) & 60 \%(74) \\ \text { None of the Time } & 6 \%(3) & 7 \%(5) & 6 \%(8)\end{array}$


3. How about the city government in Conway, how much do you trust it to do what is right?

$\begin{array}{lllr}\text { Always } & 2 \%(1) & 0 & 1 \%(1) \\ \text { Just About Always } & 4 \%(2) & 0 & 2 \%(2) \\ \text { Most of the Time } & 6 \%(3) & 18 \%(13) & 13 \%(16) \\ \text { Some of the Time } & 61 \%(32) & 66 \%(47) & 64 \%(79) \\ \text { None of the Time } & 27 \%(14) & 16 \%(11) & 20 \%(25)\end{array}$

4. Now looking at the different branches of government in Washington, which do you think can be most trusted?
Congress
$23 \%(12)$
$20 \%(14)$
$21 \%(26)$
President
$8 \%(4)$
$9 \%(6)$
$8 \%(10)$
U.S. Supreme
Court
$69 \%(36)$
$71 \%(50)$
$71 \%(86)$

5. What about state government branches, which do you think can be most trusted to do right?
Legislature
$33 \%(17)$
$30 \%(21)$
$31 \%(38)$
Governor
$20 \%(10)$
$23 \%(16)$
$22 \%(26)$
State Supreme
Court
$47 \%(24)$
$47 \%(33)$
$47 \%(57)$

6. What about local city branches of government, which can be trusted to do what is right?
City Council
$27 \%(13)$
$38 \%(26)$
$33 \%(39)$
Mayor $\quad 29 \%(14)$
$20 \%(14)$
$24 \%(28)$
City Courts
$44 \%(21)$
$42 \%(29)$
$43 \%(50)$

*This question is drawn from Joel Aberbach and Jack Walker. Race in the City (Boston: Little, Brown, 1973), p. 49.

${ }^{* *}$ The number in parenthesis is the absolute number of respondents in that cell. 
To what extent do blacks believe the system is delivering social and economic statuses and goods for them? Observing blacks' feelings of the general racial (social) climate in the United States, Schuman and Hatchett provide evidence that 38 percent of blacks thought "only a few" whites disliked blacks, 48 percent thought "most" whites disliked blacks. ${ }^{26}$ Table 7 displays (question one) that our sample is analogous to these findings, although perhaps more sanguine. Only 21 percent of our sample felt that "only a few whites dislike blacks," 42 percent believed "quite a few whites dislike blacks," and 30 percent expressed the belief that "most" whites dislike blacks and 7 percent perceived "almost all" whites dislike blacks.

\section{Table 7}

\section{Systemic Effectiveness}

1. How do you think most white Americans feel about blacks?*

Almost all whites

Black Males Black Females Total dislike blacks.

Most whites dislike blacks.

$4 \%$ ( 2)

$9 \%(6)$

$7 \%$ ( 8$)$

Quite a few whites dislike blacks.

Only a few whites dislike blacks.

$36 \%(18)$

$25 \%(18)$

$30 \%(36)$

$32 \%(16)$

$49 \%(35)$

$42 \%(51)$

$28 \%(14)$

$17 \%(12)$

$21 \%(26)$

2. Do you think that things are getting better for blacks in this country?**

No, much worse. $\quad 0$

No, a little worse.

Yes, a little

better.

Yes, much better.
$8 \%$ ( 4$)$

$70 \%(36)$

$22 \%(11)$
$2 \%(1)$

$4 \%$ ( 3$)$

$1 \%(1)$

$6 \%(7)$

$70 \%(50)$

$71 \%(86)$

$24 \%(17) \quad 23 \%(28)$ 
3. What type of a job would you like to have as your life-work when you leave college?

Socio-economic status

of job aspirations

$\begin{array}{lccr}\text { High } & 13 \%(6) & 12 \%(8) & 12 \%(14) \\ \text { Medium } & 85 \%(39) & 88 \%(60) & 87 \%(99) \\ \text { Low } & 2 \%(2) & 0 & 1 \%(1)\end{array}$

4. What type of a job do you think you will get as your life-work?

Socio-economic status

of job aspirations

$\begin{array}{lrrr}\text { High } & 9 \%(4) & 3 \%(2) & 6 \%(6) \\ \text { Medium } & 79 \%(34) & 94 \%(58) & 87 \%(92) \\ \text { Low } & 12 \%(5) & 3 \%(2) & 7 \%(7)\end{array}$

*Howard Schuman and Shirley Hatchett, Black Racial Attitudes (Ann Arbor: Institute for Social Research, 1974), p. 80. Modified by the author to reduce length of question and increase ordinal level of the alternatives.

**Ibid., p. 137. Question shortened by author and alternatives made ordinal.

With regard to blacks' perceptions of changes in the social situation, Angus Campbell reported a national survey in which 41 percent of blacks believed there had been "a lot" of change in the position of the Negro in the last few years, while 45 percent felt "some" change had occurred, and 14 percent did not perceive "much" change at all. ${ }^{27}$ Our sample of black students differ from Campbell's national sample in being somewhat more inclined to perceive an improvement for blacks (Table 7, question 2). This, as well as the preceding paragraph's findings, would be expected in light of our sample consisting of college students (i.e., societally "privileged") who have lived most of their lives in a society moving away from de jure racial discrimination. 
With regard to the deliverance of economic goods and services, it has been suggested that the basic American capitalist system has come under serious question by blacks. ${ }^{28}$ And while Schuman and Hatchett report that only 23 percent of their national sample of black Americans agreed that "a young Negro in America doesn't have much of a chance to get ahead no matter how hard he works, ${ }^{, 29}$ this feeling seems to vary by section of the country with southern blacks having higher confidence. To wit, Gary Marx found that 52 percent in New York City and 72 percent in Atlanta agreed with the statement "Negroes who want to work hard can get ahead just as anyone else". ${ }^{30}$ Arkansas black college students in this investigation were very confident that the American system would deliver the life-work that they desired and expected (Table 7, questions 3 and 4). Once again, the sample provides the response anticipated, though perhaps more sanguine than expected.

\section{Relationships}

Having described the distributions of our sample on the measures employed for support/non-support, socio-economic background, legitimacy, and systemic effectiveness we are now interested in examining the anticipated relationships suggested by literature discussed above, which are illustrated in Figure 1.

\section{Figure 1}

Political System Stability:

Anticipated Relationships

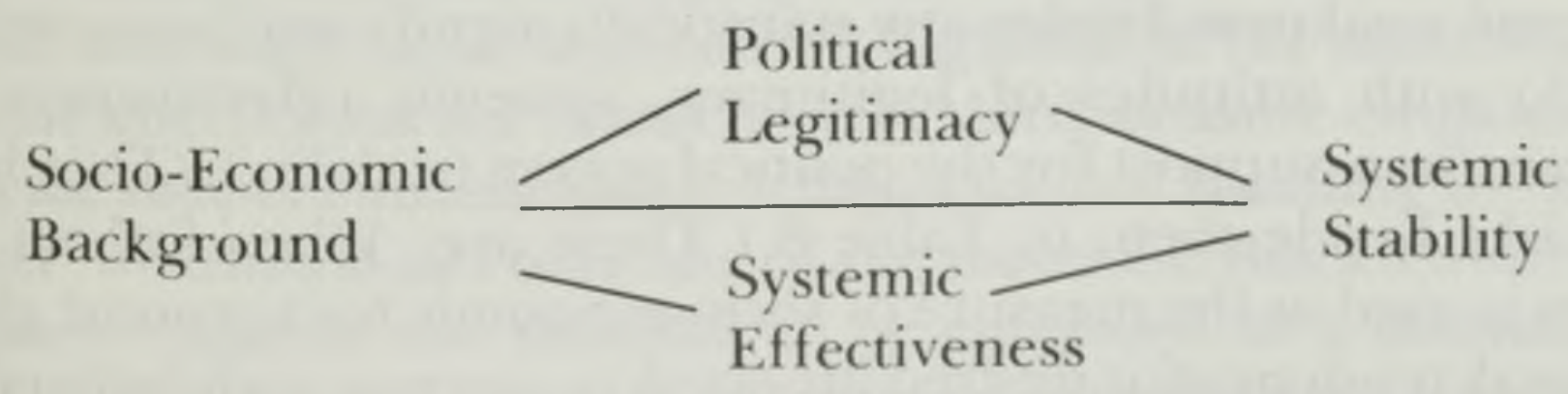

The intuitive obviousness of relationships suggested in Figure 1 belies the results of studies utilizing generally analogous conceptualizations. Abramson reports a mixture of results in his compilation of diverse studies which use different conceptualizations of 
social deprivation and legitimacy. ${ }^{31}$ Miller and associates report no relationship between their measures of "social deprivation" and black urban rioting in the $1960 \mathrm{~s},{ }^{32}$ although this is the subject of intense controversy and has been challenged on methodological grounds. ${ }^{33}$ With respect to the relationship between what can be interpreted as legitimacy and support behavior, Muller found the expected relationship among a non-random sample of college students, although the correlations were not very strong. ${ }^{34}$ However, Aberbach and Walker found tendencies for political trust (analogous to legitimacy in this paper) to be related to both conventional and unconventional political actions among a sample of blacks in Detroit. ${ }^{35}$ Citrin and associates also found a similar tendency for feelings of legitimacy (using "political alienation" in place of legitimacy) in the system to be related to both conventional and unconventional political actions in a San Francisco study. ${ }^{36}$ Muller and Jukam, employing a conceptionalization of political legitimacy and non-supportive political behavior concluded from a West German sample "low political support is a necessary but not a sufficient condition of aggressive political behavior". ${ }^{37}$ In another study with a West German sample Muller comments that "differing levels of political support are not associated with different broadly defined modes of political behavior". ${ }^{38}$

What are the relationships suggested by the conceptual diagram in our sample? In brief: very few, scattered and exceedingly weak, although in the direction predicted with only one exception. Specifically, whether fathers' or mothers' job status is used to indicate socio-economic background (Table 8), only four coefficients of extreme weakness display any statistically significant ${ }^{39}$ associations $(\leqslant .05)$ with attitudes of legitimacy, systemic effectiveness, or support/non-support for the political system (stability). (They have asterisks beside them in Table 8.) These are: When fathers job status is used as the measure of socio-economic background, there is a weak tendency for desired life-work to increase with fathers job) status $(.15$, significance level $=.004)$, and there is another weak tendency for taking part in protest marches to decrease as their fathers' job status increased $(-.14$, significance level $=.050)$. When mothers' job status was used as an indication of socio-economic background, a very slight tendency seemed to exist for those from 
homes with mothers of higher job status to: perceive the racial climate as improving (.16, significance level $=.009)$, and to perceive the meaning of black power as a fair share for blacks (.15, significance level $=.03$ ).

To complete the conceptual diagram of possible relationships, Table 9 contains the remainder of the 130 possibilities among the measures employed in this work. The conceptual diagram anticipates that legitimacy and systemic effectiveness will be associated with systemic stability (support/non-support actions). Of the 130 possibilities there are 19 coefficients that are statistically significant at $\leqslant .05$. They have asterisks beside them in Table 9 . None is of any strength usually ranging from .08 to .15 , with .30 the strongest. Yet, with the exception of one (infinitesimally slight tendency - if at all - to support taking part in a riot as trust in state government increases: .09 , significance $=.036$ ), these coefficients are all in the direction that would be predicted by Figure 1. The highest coefficient, and perhaps the only one worth commenting on individually, is a .30 between decreasing support for racial separation as preception of whites' hostility decreases. Thus, even the strongest coefficient is weak.

By way of highlighting Table 9, three of the six measures of legitimacy (trust in national, state and local government), along with three of the four measures of systemic effectiveness (perception of whites' attitudes toward blacks, of improvement in the racial climate, and job status aspiration) display weak scattered associations with two of the measures of supportive/non-supportive activities (tactics considered appropriate to achieve blacks' political needs, and black racial separation). Eighteen of the nineteen significant coefficients are found here. A third measure employed to indicate support/non-support - the perceived meaning of "black power" - contributes only one of the nineteen. Black Power - a slogan - may be too symbolic to be employed as a meaningful indicator of systemic support, it being meaningful perhaps only in extreme cases, e.g., H. Rap Brown. 


\section{Table 8}

Family SES Background Indexes With Feelings of Legitimacy, Effectiveness, and Supportive Attitudes

Fathers' Occupational Status as Family SES Indicator

Mothers' Occupational Status as Family SES Indicator

$$
\begin{aligned}
& \begin{array}{llllllll}
\text { V1 } & \text { V2 } & \text { V3 } & \text { V4 } & \text { V5 } & \text { V6 } & \text { V7 } & \text { V8 }
\end{array} \\
& \begin{array}{llllllll}
0.068^{\mathrm{a}} & .002 & -.045 & .00 & .00 & .047 & .002 & -.030
\end{array} \\
& \text { Sig=.18 Sig=.44 Sig=.49 } \quad \text { Sig=.76 } \quad \text { Sig=.86 } \quad \text { Sig=.33 } \quad \text { Sig=.49 } \quad \text { Sig=.37 } \\
& \begin{array}{llllllll}
.006 & -.07 & .03 & .05 & .03 & .02 & -.02 & .16^{*}
\end{array} \\
& \text { Sig=.46 Sig=.16 Sig=.30 Sig=.11 Sig=.34 Sig=.45 } \quad \text { Sig=.38 } \quad \mathrm{Sig}=.009 \\
& \begin{array}{llllllll}
\text { V9 } & \text { V10 } & \text { V11 } & \text { V12 } & \text { V13 } & \text { V14 } & \text { V15 } & \text { V16 }
\end{array} \\
& \begin{array}{llllllll}
.035 & .15^{*} & -.043 & -.021 & -.016 & -.128 & .081 & .05
\end{array} \\
& \text { Sig=.25 Sig=.004 Sig=.29 Sig=.40 Sig=.41 } \quad \text { Sig=.069 } \quad \text { Sig=.14 } \quad \text { Sig=.23 } \\
& \begin{array}{llllllll}
-.05 & -.02 & -.02 & -.10 & .09 & .05 & .15^{*} & -.01
\end{array} \\
& \text { Sig=.15 Sig=.34 Sig=.37 Sig=.13 Sig=.11 } \quad \text { Sig=.28 } \quad \text { Sig=.03 } \quad \text { Sig=.41 } \\
& \begin{array}{lllllll}
V 17 & V 18 & V 19 & V 20 & \text { V21 } & \text { V22 } & \text { V23 }
\end{array}
\end{aligned}
$$$$
\text { (Continued) }
$$$$
\text { Fathers' Occupational }
$$$$
\text { Status as Family SES }
$$$$
\text { Indicator }
$$

Mothers' Occupational Status as Family SES Indicator

(Continued)

Fathers' Occupational Status as Family SES

$\begin{array}{lllllll}-.06 & .005 & -.14^{*} & .001 & .138 & -.05 & .03\end{array}$


Mothers' Occupational

Status as Family SES Indicator

$\begin{array}{lllll}.01 & -.02 & -.002 & -.04\end{array}$

Sig $=.41 \quad$ Sig $=.37$
Sig $=.48$
.05

Sig $=.25 \quad$ Sig $=.17 \quad$ Sig $=.32$

Statistically significant. See note 39.

The coefficients are Kendall's tau B or C, depending upon which is appropriate, for all variables except V4 through V 17 which are Lambda Asymmetrics with Chi Square as test of significance. The top number is, of course, the coefficient with the signficance level immediately below it. Thus, to interpret this first cell, there is a .068 correlation between respondents' Fathers' Occupational Level and Trust in the national government (V1), it is not significant with a statistical significance level of .18.

LEGEND: V1 = trust in national government; V2 = trust in state government; V3 = trust in city government; $V 4=$ most trusted branch of national government; V $5=$ most trusted state branch of government; V6 = most trusted branch of city government; V7 = perception of whites' feelings about blacks; V8 = perception of improvement in racial climate; V9 = desired life-work; V10 = expected life work; VII = attitude toward racial separation; V12 = "black power" perceived as black rule over whites; V13 = "black power" as violence; V14 = "black power" as ridicule of whites; V15 = "black power" as fair share for blacks; V16 = "black power" as black racial unity. V17 = contacting public officials as appropriate tactic; V 18 = campaigning for black candidates as appropriate tactic; V 19 = taking part in protest meeting or marches as appropriate tactic; V20 = campaigning against certain political officials as appropriate tactic; V21 = taking part in sit-in's as appropriate tactic; V22 = refusing to obey a law that is unjust as appropriate tactic; V23 = taking part in a riot as appropriate tactic. 


\section{Table 9}

\section{Relationships ${ }^{\text {a }}$ of Systemic Legitimacy and Effectiveness With Systemic Stability Among Blacks}

BLACKS' TACTICS

1. Campaigning for black candidates.

2. Contacting public officlas.

3. Campaigning against officials.

4. Taking part in protest meetings.

5. Taking part in sit-ins.

6. Refusing to obey unjust laws.

7. Taking part

in a riot.

$\begin{array}{clllllllll}\text { V1 } & \text { V2 } & \text { V3 } & \text { 'v4 } & \text { V5 } & \text { V6 } & \text { V7 } & \text { V8 } & \text { V9 } & \text { V10 } \\ \text { Coeff. }=-.13^{*} & -.11^{*} & -.045 & .00 & .00 & .00 & .12^{*} & -.02 & .01 & .04 \\ \text { Sig. }=025 & .051 & .209 & .456 & .595 & .434 & .053 & .365 & .404 & .208 \\ \text { Coeff. }=.15^{*} & .12 & .10^{*} & .00 & .00 & .00 & .08 & .11^{*} & -.14^{*} & -.007 \\ \text { Sig. }=.015 & .033^{*} & .045 & .815 & .841 & .801 & .112 & .038 & .003 & .450 \\ \text { Coeff. }=-.193^{*} & -.10 & -.07 & .00 & .00 & .00 & -.07 & -.05 & .04 & .01 \\ \text { Sig. }=.002 & .068 & .107 & .562 & .822 & .417 & .177 & .212 & .250 & .417 \\ \text { Coeff. }=-.03 & -.02 & -.05 & .00 & .00 & .00 & -.07 & -.08 & .08^{*} & .01 \\ \text { Sig. }=.336 & .362 & .200 & .881 & .814 & .718 & .153 & .089 & .048 & .338 \\ \text { Coeff. }=.04 & .02 & -.02 & .01 & .00 & .00 & -.09 & -.04 & .01 & -.04 \\ \text { Sig. }=.277 & .409 & .369 & .808 & .405 & .309 & .115 & .262 & .436 & .226 \\ \text { Coeff. }=.11 * & -.01 & -.01 & .00 & .00 & .00 & -.15^{*} & .01 & .099^{*} & .03 \\ \text { Sig. }=.049 & .470 & .437 & .737 & .368 & .491 & .018 & .419 & .026 & .259 \\ \text { Coeff. }=.03 & .09^{*} & .06 & .00 & .00 & .00 & -.10^{*} & .00 & .06 & .01 \\ \text { Sig. }=.258 & .036 & .083 & .265 & .539 & .275 & .041 & .498 & .081 & .376\end{array}$


MEANING OF BLACK POWER

I. Black racial

\begin{tabular}{|c|c|c|c|c|c|c|c|c|c|}
\hline Coeff. $=-.01$ & .05 & -.03 & .00 & .00 & .00 & -.02 & .01 & .01 & .02 \\
\hline Sig. $=.468$ & .196 & .326 & .146 & .889 & .323 & .381 & .403 & .414 & .358 \\
\hline Cocff $=.07$ & .02 & .03 & .02 & .00 & .00 & -.00 & .06 & .07 & $.10^{*}$ \\
\hline Sig. $=.147$ & .359 & .309 & .15 & .740 & .775 & .496 & .155 & .113 & .019 \\
\hline Coeff. $=.01$ & -.09 & -.02 & .00 & .00 & .00 & .02 & -.03 & -.01 & -.03 \\
\hline Sig. $=.418$ & .104 & .329 & .273 & .844 & .911 & .422 & .280 & .437 & .279 \\
\hline Coeff. $=-.04$ & -.01 & .01 & .07 & .04 & .03 & .04 & .01 & -.01 & -.02 \\
\hline Sig. $=.268$ & .467 & .440 & .307 & .523 & .530 & .291 & .496 & .457 & .288 \\
\hline Coeff. $=-.00$ & .02 & .02 & .08 & .00 & .00 & -.09 & -.06 & -.03 &.$-(0) 1$ \\
\hline Sig. $=.489$ & .362 & .373 & .071 & .375 & .158 & .084 & .136 & .262 & .392 \\
\hline Coeff. $=-.05$ & -.11 & $-.22^{*}$ & .00 & .00 & .00 & $.30^{*}$ & $-.15^{*}$ & .01 & .00 \\
\hline Sig. $=.276$ & .105 & .010 & .180 & .610 & .726 & .000 & .009 & .436 & .461 \\
\hline
\end{tabular}

unity.

2. Fair share

for blacks.

Black rule

wer whites.

Ridicule of

whites.

¡. Violence

Sig. $=.276$

.010 .180

.610

BLACK RACIAL.
SEPARATION

* Statistically significant. See note 39.

a The coefficients in this table are Kendall's Tau B or C (depending on which is appropriate) for all the variables except V4 through V6. For these Lambda Asymmetrics are employed with Chi Square as the test of significance.

L.EGND: $\mathrm{Vl}=$ trust in national government; $\mathrm{V} 2=$ trust in the state government; $\mathrm{V} 3=\mathrm{trust}$ in the local government; V4 = national branch most trusted; V5 = state branch most trusted; V6 = local branch most trusted; V7 = perception of white feelings toward blacks; V8 = perception of improvement in blacks' situation; V9 = job status aspiration; V10 = job status expected. 


\section{Summary}

Regarding the distribution of the three measures used to indicate systemic stability (support/non-support for the political system): (1) The black students ranked non-violent, within-the-system activities as the most appropriate tactics for blacks to engage in; within-the-system protest activities next; and, non-supportive actions lowest (Table 1). (2) Their rankings of the meaning of "black power" placed emphasis upon within-the-system interpretation (Table 2). (3) There is strong support for black group-voting and for political individuality with females significantly more inclined to opt for an individualistic orientation (the only male/female significant difference in the study); little support existed for black group hegemony; and, no support is registered for racial separation (Table 3). The distributions of these responses are in close congruence with published literature discussed in the body of this paper.

The sample contains the anticipated low level of socioeconomic family background status with females and males having the same pattern (Table 4). Regarding the description of the sample's distributions of feelings toward the system, they display high support for the abstract notion of the American nation (Table 5), but fairly low support for the different levels of American government, with support for the United States Supreme Court the highest among the branches of government (Table 6). These correspond to other published research discussed above.

With respect to the distributions of the four questions (Table 7) employed to measure systemic effectiveness: (1) over one-half of the sample of black students perceive the general racial situation as hostile, but (2) overwhelmingly feel the situation is improving. And (3) they express pronounced confidence in the capacity of the system to deliver the life-work they would like to have. These responses are more sanguine then samples of blacks cited in the literature from the 1960 's and early 1970 's. This greater confidence may reflect the "privileged" status this sample possesses as college students. Also, they have grown up in a system moving away from de jure racial discrimination.

Finally, the relationships predicted by the diagram in Figure $1^{40}$ were only very vaguely found in this data. Only a few scattered 
and very weak associations were found although in the direction predicted.

\section{Conclusions}

The theory that socio-economic backgrounds affect attitudes toward systemic legitimacy and effectiveness which in turn affect conventional/unconventional political behaviors (systemic stability) contains too much accumulated - if unsystematic - experience to reject on the basis of a few non-definitive studies. Instead, refinements and qualifications seem more appropriate at this time.

First, the theory itself seems to require additional variables. Muller and Jukam have suggested that ideological beliefs and the community context within which the political behaviors occur are important factors with respect to potential relationships between legitimacy and conventional/unconventional political behaviors. ${ }^{41}$ In another work Muller suggests that belief in one's own personal political influence plus belief in the efficacy of (recent) past colleclive actions taken (by similarly situated persons) ${ }^{42}$ are important stimulants to unconventional political behaviors. ${ }^{43}$ Finally, he suggests that "personal" deprivation may be important in unconventional political behavior, ${ }^{44}$ although as earlier discussed Miller and associates in a controversal article reported no association of "relative" deprivation with unconventional political behavior among blacks. ${ }^{45}$

Akin to the notion of "personal" or "relative" deprivation is that of social mobility. Robert Lane has suggested that only a mild amount of social mobility is required to satisfy life aspirations enough to prevent active dissatisfaction with the overall system. ${ }^{46}$ Both personal/relative deprivation and social mobility, however, seem to require being placed within the larger context of the person's general expectations from the system. That is, a group of persons who have developed a high set of expectations regarding what a system is capable of doing, and/or, have developed, a set of reparation expectations for the past non-delivery of that system, may have negative feelings toward the legitimacy and effectiveness of that system and may engage in unconventional political behaviors despite possessing considerable social mobility and/or low actual relative deprivation. 
Second, the variables in the theory require considerable refinement with respect to meaning and measurement. For example Crosby's critique of Miller and associates is illustrative on the variable of relative deprivation. ${ }^{47}$

Finally, even if various suggestions are taken in future research, the relationships predicted by the theory might still display only moderate strength. This is anticipated by the author because of the well-documented inconsistencies between political attitudes and behaviors of which the Prothro/Grigg and McCloskey studies are exemplary. ${ }^{48}$ They conclude that it is learned patterns of actual political behavior that are most consistent, not political attitudes and political behaviors. Thus, even solid samples of unconventional political activists may well display only moderate strength of relationships between their political attitudes and unconventional politics.

Moreover, specifically among blacks, this general possession of inconsistent political attitudes/behaviors may be expected to have been reinforced by their particular circumstances of the recent past. This subcultural hypothesis of black political socialization merits much more research. ${ }^{49}$ 


\section{Notes}

Acknowledgments: The University of Central Arkansas, particularly the Department of Political Science, merits gratitude for supplies and computer services. Two anonymous referees from the Arkansas Political Science Association are to be thanked for their critiques.

1. Ermest Barker, ed. and trans., Politics of Aristotle (New York: Oxford, 1962), pp. 202-254. 2. Eduard N. Muller, "Correlates and Consequences of Beliefs in the Legitimacy of Regime Structures," Midwest Journal of Political Science, 14 (August, 1970), 392-397.

3. Paul R. Abramsom, The Political Socialization of Black Americans (New York: Free Press, 1977), pp. 36-55.

4. Faye Crosby, "Relative Deprivation Revisited: A Response to Miller, Bolce, and Halligan." American Political Science Review, 73 (March, 1979), 103-112.

5. Darid Eastom, A Systems Analysis of Political Life (Neu' York: Wiley, 1965), pp. 1-100.

6. Muller, 1970, p. 392.

7. Snmour Martin Lipset, Political Man (Garden City: Doubleday, 1960), pp. 68-70.

8. We are not dealing with the notion of an individual's perception of personal political efficacy.

9. Lester Milbrath, Political Participation(Chicago: Rand McNally, 1965), pp. 58, 63, 138-141.

10. Donald. Mattheu's and James Prothro, Negroes and the New Southern Politics (New York: Harcourt, 1966), p. 55.

11. Sidney Verba and Norman Nie, Participation in America (New York: Harper and Row, 1972), pp. $149-173$.

12. Joe Feagan and Harlan Hahn, Ghetto Revolts (New York: Macmillan, 1973), p. 102.

13. Angus Campbell and Howard Schuman, Racial Attitudes in Fifteen Cities (Ann Arbor: Institule for Social Research, 1968), p. 52.

14. Ibid., p. 47.

15. Ibid., p. 57.

16. Joel Aberbach and Jack Walker, Race in the City (Boston: Little, Brown, 1973), p. 109.

17. Ibid., p. 159.

18. Ibid., p. 109.

19. Raymond Franklin and Solomon Resnik, Political Economy of Racism (New York: Holt, Rinehart, and Winston, 1973), pp. 36-54.

20. Milton Morris, The Politics of Black America (New York: Harper, 1975), p. 126.

21. Gary Marx, Protest and Prejudice (New York: Harper, 1969), p. 30.

22. Abramson, pp. 4-10.

23. Campbell and Schuman, p. 41.

24. Aberbach and Walker, p. 183.

25. Hebert Hirsch and Lewis Donohew, "A Note on Negro-White Differences toward the Supreme Court," Social Science Quarterly, 40 (December, 1968), 562.

26. Howard Schuman and Shirley Hatchett, Black Racial Attitudes (Ann Arbor: Institute for Social Research, 1974), p. 80.

27. Angus Campbell, White Attitudes toward Black People (Ann Arbor: Institute for Social Research, 1977), p. 137.

28. Morris, p. 127.

29. Schuman and Hatchett, p. 79.

30. Marx, p. 24.

31. Abramson, pp. 36-55. There are a plethora of different conceptualizations reported by Abramson. This author is including the materials Abramson referred to as "social deprivation" with the "socioeconomic background" concept in this work. Also, the studies compiled by Abramson under the name of "political trust" are rieued as similar to "legitimacy" in this paper.

32. Abraham Miller, Louis H. Bolce, and Mark Halligan, "The J-Curve Theory and the Black Urban Riots," American Political Science Review, 71 (September, 1977), 964-982.

33. Crosbry, see note 4, above.

34. Muller, 1970, p. 402

35. Aberbach and Walker, p. 206

36. Jack Citrin, Herbert McCloskey, J. Merrill Shanks, Paul M. Sniderman, "Sources and Consequences of Political Alienation: A Progress Report," paper delivered at the comference on "Support for 
the System," Madison, Wisconsin, Augrust 12-17, 1973.

37. Edward Muller and Thomas Jukam, "On the Meaning of Political Support," American Political Science Review, 71 (December, 1977), 1574.

38. Edward Muller, "Behazioral Correlates of Support," American Political Science Review, 71 (June, 1977), 461.

39. Given that the sample is not random, statistical significance tests are not strictly in order, but are used as suggestive.

40. The author has intenticmally avoided the use of terms such as "model" or "causation." A causal analysis was originally planned but the very weak relationships made it superfluous.

41. Muller and Jukam, p. 1589.

42. The parenthetical phrases are my qualifying interpretations to his suggestions. Incidentally, these two studies by Muller were not available at the time this paper was conceptualized and data collected. 43. Muller, "Behavioral Correlates of Support," p. 461.

44. Ibid., p. 466. I view "personal" deprivation and "relative" deprivation as interchangeable. 45. See notes 32 and 4, above.

46. Robert Lane, "The Fear of Equality," American Political Science Review, 53 (March, 1959), 35-51.

47. See note 4.

48. Charles Cnudde and Dean Neubauer, eds., Empirical Democratic Theory (Chicago: Markham, 1969), pp. 236-252, 268-302.

49. Abramson, pp. 90-91. 